\title{
Anomali Kewenangan Dewan Pimpinan Pusat \\ Partai Politik dalam Sistem Desentralisasi \\ Pemerintahan di Indonesia
}

\author{
Wawan Gunawan \\ wagoenbray@yahoo.com
}

\section{Dosen FISIP Universitas Jenderal Achmad Yani}

\begin{abstract}
Abstrak
Sekurangnya ada dua fenomena yang menarik untuk dicermati. Pertama, di ranah suprastruktur politik, pemerintah (eksekutif) telah mengimplementasikan desentralisasi kekuasaan, sehingga hanya tinggal 6 bidang saja yang menjadi kewenangan pusat; kewenangan lain telah didistribusikan ke pemerintah daerah. Kedua, di ranah infrastruktur politik, terjadi sentralisasi kewenangan di tangan Dewan Pimpinan Pusat (DPP) Partai Politik, khususnya di tangan Ketua Umum dan Sekretaris Jenderal, dalam hal menentukan calon kepada daerah; Calon gubernur/wakil gubernur, calon walikota/wakil walikota, calon bupati/wakil bupati. Sehingga, kewenangan Dewan Pimpinan Daerah dan Dewan Pimpinan Cabang tidak memiliki kewenangan yang signifikan di hadapan DPP. Inilah fenomena anomali kewenangan DPP partai politik dalam sistem desentralisasi pemerintahan di Indonesia. Desentralisasi sebagai sebuah prasyarat demokrasi seakan tidak berarti dalam struktur partai politik.
\end{abstract}

Kata Kunci: Anomali kewenangan Dewan Pimpinan Pusat Partai Politik, sistem desentralisasi pemerintahan.

\section{Latar Belakang}

Pasca reformasi, menurut Warganegara (2011: 307), Indonesia berada dalam transisi demokrasi. Era transisi demokrasi ini, dalam pandangan Sorensen (2003: 71) mendorong lahirnya kajian konsolidasi demokrasi sebagai tahapan pendalaman demokrasi yang ditandai pembentukan lembaga demokrasi. Itulah sebabnya, menurut Smith (2003: 76-78), salah satu tuntutan reformasi adalah adanya pemilihan umum kepala daerah yang dilaksanakan secara langsung. Pemilihan umum kepala daerah yang diselenggarakan secara langsung ini merupakan konsekuensi dari desentralisasi. 
Dalam upaya mendiskusikan urgensi desentralisasi, setikdanya ada dua isu yang menarik dicermati: Pertama, di ranah suprastruktur politik, dalam hal ini eksekutif, desentralisasi sudah diimplementasikan. Istilah desentralisasi sebenarnya adalah istilah dalam keorganisasian yang secara sederhana didefinisikan sebagai penyerahan kewenangan (Haris, 2007: 52).

Menurut Kaho (1997: 12), tujuan desentralisasi adalah, (a) mengurangi bertumpuknya pekerjaan di Pusat Pemerintahan, (b) dalam menghadapi masalah yang amat mendesak yang membutuhkan tindakan yang cepat, daerah tidak perlu menunggu instruksi lagi dari Pemerintah Pusat, (c) dapat mengurangi birokrasi dalam arti yang buruk karena setiap keputusan dapat segera dilaksanakan, (d) dalam sistem desentralisasi, dapat diadakan pembedaan dan pengkhususan yang berguna bagi kepentingan tertentu. Khususnya desentralisasi teritorial, dapat lebih mudah menyesuaikan diri kepada kebutuhan dan kebutuhan khusus daerah, (e) mengurangi kemungkinan kesewenang-wenangan dari Pemerintah Pusat, (f) dari segi psikologis, desentralisasi dapat lebih memberikan kepuasan bagi daerah-daerah karena sifatnya yang lebih langsung.

Dari dua pendapat tersebut jelas bahwa desentralisasi menjadi penting di dalam mengatur dan mengelola urusan pemerintahan yang memang tidak sedikit, tidak gampang, dan sangat rumit, sehingga dresentralisasi menjadi pilihan pemerintah untuk menyelesaikan berbagai urusan yang menjadi tanggungjawabnya, sehingga kemudian menjadi jelas batasan mana urusan pemerintah pusat dan mana urusan pemerintahan daerah: Siapa mengerjakan apa dan bertanggungjawab kepada siapa, menjadi jelas.

Namun demikian, isu yang kedua, di ranah infrastuktur politik, dalam hal ini partai politik, setidaknya hingga hari ini, terjadi sentralisasi kewenangan di tangan Dewan Pimpinan Pusat (DPP) Partai Politik, khususnya di tangan Ketua Umum dan Sekretaris Jenderal, dalam hal menentukan calon kepada daerah; Calon gubernur/wakil gubernur, calon walikota/wakil walikota, calon 
bupati/wakil bupati. Sehingga, kewenangan Dewan Pimpinan Daerah dan Dewan Pimpinan Cabang tidak memiliki kewenangan yang signifikan di hadapan DPP. Inilah fenomena anomali kewenangan DPP partai politik dalam sistem desentralisasi pemerintahan di Indonesia. Desentralisasi sebagai sebuah prasyarat demokrasi seakan tidak berarti dalam struktur partai politik.

Fenomena ini dapat dicermati dalam dinamika politik jelang pilkada serentak 2018. Seperti di Jawa Barat, Partai Golkar pada November 2017 lalu mendukung Walikota Bandung Ridwan Kamil untuk maju sebagai bakal calon gubernur bersama Daniel Muttaqien, padahal sebelumya DPD Provinsi Golkar Jawa Barat hanya mengusulkan Dedi Mulyadi untuk maju pada pilgub Jabar 2018 (http://m.republika.co.id/berita/nasinal/pilkada/17/10/28, diunduh 04/ 01/ 18) Keputusan DPP Partai Golkar tersebut tidak sejalan dengan usulan partai ditingkat daerah. Sebagian besar pengurus partai Golkar ditingkat DPD Kota/Kabupaten hingga tingkat ranting di Jawa Barat kecewa dan menolak kandidat yang didukung DPP Partai Golkar (http:// metrotvnews.com /read/2017/11/07/78462/kader-golkar-bakal-laporkan-pengusungan-emil-kemahkamah-partai, diunduh 04/01/18.)

Demikian halnya yang terjadi pada partai Gerindra, pencalonan Mayjen (Purn) Sudrajat (http://regional.kompas.com/read/2018/01/07, diunduh tanggal 08/01/17) di pilgub Jabar berbeda dengan aspirasi dan keinginan kader daerah hasil penjaringan yang tiga nama yaitu ; Deddy Mizwar, Ahmad Syaikhu dan Ketua Gerindra Provinsi Jabar Mulyadi untuk maju sebagai kandidat (http://m.republika.co.id/berita/nasional/pilkada/1708/10, diunduh tanggal 08/01/18). Dan ironisnya nama Mayjen (Purn) Sudrajat sebelumnya tidak pernah mengikuti penjaringan yang dilaksanakan DPD Gerindra Jabar, tetapi langsung ditunjuk Ketua Dewan Pembina Partai Gerindra untuk maju sebagai cagub Jabar.

Di tingkat Kabupaten/Kota juga terjadi hal serupa. Seperti bakal calon walikota Bandung yang diusung partai Demokrat. Sebelumnya DPC Demokrat 
Kota Bandung merekomendasikan Yossi Irianto ke DPP Partai Demokrat sebagai calon walikota Bandung dalam pilkada sentrak 2018, (https://m.detik.com/news/berita-jawa-barat/d-3713199/demokrat-bandungrekomendasikan-yossi-ke-dpp-jadi-calon-wali-kota, diunduh 08/01/18), namun DPP memutuskan nama Nurul Arifin dan Chairul Yaqien Hidayat sebagai calon walikota dan calon wakil walikota Bandung yang diusung Partai Demokrat (http://m.liputan6.com/news/read/3157712/demokrat-usung-nurularifin-chairul-yaqin-untuk-pilwalkot-bandung, diundul 08/01/18).

Pola-pola sentralistik yang diperagakan partai politik tentu menjadi anomali bahkan ironi dan bisa jadi kontraproduktif terhadap proses demokrasi yang terus digalakan pemerintah hingga tingkat terendah. Pelaksanaan desentralisasi atau pelimpahan wewenang yang merupakan bagian integral demokrasi tidak terwujud dalam partai politik yang selama ini getol menyuarakan demokratisasi.

Keputusan DPP Partai Politik yang sentralistik dan absolut menjadi preseden buruk bagi perkembangan kader politik di daerah. Wajar jika kemudian partai politik sangat minim melahirkan kader emas, karena memang tidak dibangun sistem kompetisi yang fair untuk para kader partai. Selain gagal dalam menciptakan kader emas, kondisi ini dapat mematikan loyalitas dan karier politik kader didaerah. Banyaknya „kutu loncat ${ }^{\text {ee }}$ yang berpindah partai bisa diindikasikan kekecewaan kader terhadap sistem politik internal partai dan ketidakjelasan karier politiknya.

Jika mencermati kondisi tersebut tampak bahwa partai politik di daerah tidak memiliki kewenangan apapun dalam menentukan kandidat/calon bagi kepala daerah yang akan maju dalam kontestasi pilkada baik di tingkat provinsi, kabupaten maupun kota. Seluruh keputusan sangat bergantung pada pusat, daerah hanya tinggal menjalankan kendati hal tersebut bertentangan dengan aspirasi daerah. 
Dengan kata lain terjadi anomali dalam sistem politik pemilu di Indonesia. Pemerintah berupaya menyelenggarakan demokrasi hingga tingkat terendah melalui sistem desentralisasi, sementara partai politik sebagai infrastruktur politik, terutama dalam menentukan calon yang akan menjadi kepala daerah, tidak berjalan secara demokratis. Hegemoni dan sentralistik menjadi sistem politik yang dianut partai politik dalam pengambilan keputusan.

\section{Kajian Pustaka}

\section{Pilkada dalam Bingkai Demokrasi}

Demokrasi mensyaratkan adanya pelaksanaan Pemilihan Umum (Schumpeter,1942; Huntington, 1995; Apter, 1995; Dahl, 2001; Surbakti, 1992). Sedangkan Demokrasi menurut Held (1996: 1) adalah bentuk atau sistem pemerintahan yang seluruh rakyatnya turut serta memerintah dengan perantaraan wakilnya, atau disebut juga pemerintahan rakyat.

Apa yang dikatakan Held tersebut adalah yang bersifat "seharusnya" tetapi dalam kenyataannya, apa yang disebut sebagai "pemerintahan rakyat" hanyalah lips service belaka sebab ada banyak kasus yang justru menunjukan bahwa yang ada adalah pemerintahan elit dimana kaum yang memiliki kekusaan berkolaborasi dengan kaum pemilik modal, dan dua kaum inilah yang sesungguhnya mengatur jalannya pemerintahan dan sekaligus mengatur kehidupan rakyat.

Itulah sebabnya Treanor (2001: 1) mengatakan bahwa demokrasi telah gagal. Komponen etika demokrasi disebut yang pertama dan terpenting sangat jelas jarang disebut secara eksplisit. Ia adalah prinsip etika dan legitimasi politik: Lebih lanjut Treanor (2001: 57-59) mengatakan bahwa demokrasi itu sebuah paradoks: Semestinya sebuah pemerintahan yang demokratis seharusnya tidak digulingkan tetapi dalam realitasnya banyak dari pemerintahan yang menganut sistem demokrasi pada gilirannya digulingkan atas tuduhan tidak demokratis. 
Terlepas dari analisis Treanor sebagaimana disebutkan di atas, soal kegagalan demokrasi, namun yang jelas hingga sekarang konsep demokrasi masih digunakan sebagai landasarn penyelenggaraan pemerintahan di banyak negara. Paling tidak, sebagaimana dikemukakan oleh Dahl (2001: 52-53) bahwa demokrasi adalah suatu sistem politik yang memberikan kesempatan untuk beberapa hal berikut ini. Pertama, sebelum sebuah kebijakan dibuat, masyarakat harus mempunyai kesempatan yang sama dan efektif untuk membuat pandangan mereka diketahui oleh anggota-anggota lainnya, sebagaimana seharusnya kebijakan itu dibuat. Kedua, masyarakat harus mempunyai kesempatan yang sama dan efektif untuk memberikan suara dan seluruh suara harus dihitung sama. Ketiga, masyarakat harus mempunyai kesempatan yang sama dan efektif untuk mempelajari kebijakan-kebijakan alternatif yang relevan dan konsekuensi yang mungkin. Keempat, masyarakat harus mempunyai kesempatan eksklusif untuk memutuskan bagaimana dan apa permasalahn yang dibahas dalam agenda kebijakan. Kelima, masyarakat memiliki hak kewarganegaraan penuh yang ditunjukkan oleh empat kriteria sebelumnya.

Sebagaimana dikemukakan di atas, salah satu kesempatan yang harus dapat dirasakan oleh masyarakat adalah pelibatan masyarakat dalam proses pengambilan kebijakan publik sehingga terjadi penguatan peran masyarakat yang ditandai dengan munculnya civility, yaitu ketertiban masyarakat yang terjadi bukan karena paksaan tetapi karena kebutuhan masyarakat luas (Chandaoke, 1995: 34).

Hal tersebut dapat dipahami karena memang penguatan masyarakat warga merupakan faktor determinan dalam proses pengambilan kebijakan publik yang melibatkan segenap lapisan sosial. Ada dua pola yang dapat dilakukan dalam rangka menggalang partisipasi masyarakat untuk pembuatan kebijakan publik di era demokratisasi, yaitu partisispasi tidak langsung, seperti partisipasi melaui media massa (cetak dan elektronik), dan partisipasi 
langsung dengan menggunakan struktur - struktur mediasi. Dengan demikian, partisipasi masyarakat dibutuhkan dalam proses berdemokrasi.

Sejak diberlakukannya UU Nomor 23 tahun 2014 tentang Pemerintahan Daerah yang merupakan penyempurnaan dari UU Nomer 32 tahun 2004 dan UU Nomor 10 tahun 2016 tentang Perubahan Kedua Atas UU Nomor 1 tahun 2015 Tentang Penetapan Peraturan Pemerintah Pengganti Undang-Undang Nomor 1 tahun 2014 Tentang Pemilihan Gubernur, Bupati dan Walikota menjadi Undang-Undang, pemilihan kepala daerah tidak lagi dilakukan melalui lembaga perwakilan rakyat. Melalui UU 23 tahun 2014, masyarakat dapat menentukan kepala daerahnya sesuai dengan kebutuhan dan keinginannya melalui mekanisme Pemilihan Umum Kepala Daerah Langsung.

Menurut Yusdianto (2010: 44), pilkada merupakan instrumen yang sangat penting dalam penyelenggaraan Pemerintah Daerah berdasarkan prinsip demokrasi karena rakyat secara langsung akan memilih pemimpinnya di daerah sekaligus memberikan legitimasi kepada siapa yang berhak dan mampu untuk memerintah.. Hal ini sejalan dengan pendapatnya Haris (2000: 32) bahwa semangat otonomi adalah pengakuan terhadap aspirasi dan inisiatif masyarakat lokal (daerah) untuk menentukan nasibnya sendiri.

Dalam pandangan Smith (2003: 76-77) terdapat beberapa argumen mengapa dibutuhkan Pilkada: Pertama, Pilkada diperlukan untuk meningkatkan kualitas akuntabilitas para elit politik lokal, termasuk kepalakepala daerah. Kedua, Pilkada diperlukan untuk menciptakan stabilitas politik dan efektifitas pemerintahan di tingkat lokal. Ketiga, Pilkada akan memperkuat dan meningkatkan kualitas seleksi kepemimpinan nasional karena makin terbuka peluang bagi munculnya pemimpin-pemimpin nasional yang berasal dari bawah dan/atau daerah. Hal ini sejalan dengan salah satu tujuan desentralisasi dan otonomi daerah yaitu dalam rangka pelatihan dan kepemimpinan nasional. Keempat, Pilkada merupakan wadah dimana masyarakat lokal menyalurkan aspirasi politiknya untuk memilih pemimpin 
daerah sesuai dengan hati nuraninya masing-masing tanpa adanya intervensi dari pemerintah pusat.

Berdasarkan ukuran-ukuran demokrasi, menurut Suharizal (2011: 8-9) bahwa: Pilkada menawarkan sejumlah manfaat dan sekaligus harapan bagi pertumbuhan, pendalaman dan perluasan demokrasi lokal. Pertama, sistem demokrasi langsung melalui Pilkada akan membuka ruang partisipasi yang lebih luas bagi warga dalam proses demokrasi dan menentukan kepemimpinan di tingkat lokal. Kedua, Pilkada memungkinkan munculnya secara lebih lebar preferensi kandidat-kandidat berkompetensi dalam ruang yang lebih terbuka. Ketiga, Pilkada memberi peluang bagi warga untuk mengaktualisasi hak-hak politiknya secara lebih baik tanpa direduksi oleh kepentingan-kepentingan elite politik seperti yang kasat mata muncul dalam sistem demokrasi perwakilan. Keempat, Pilkada memperbesar harapan untuk mendapatkan figur pemimpin yang aspiratif, kompeten dan legitimate. Kelima, kepala daerah yang terpilih melalui Pilkada akan memiliki legitimasi politik yang kuat sehingga akan terbangun perimbangan kekuatan (check and balance) di daerah antara kepala daerah dengan DPRD.

Pilkada, menurut Azis (2011: 6-7), merupakan proses politik yang tidak saja merupakan mekanisme politik untuk mengisi jabatan demokratis tetapi juga sebuah implementasi pelaksanaan otonomi daerah yang sesungguhnya. Sedangkan menurut Rozali (2009: 168): Setiap warga negara Indonesia yang pada hari pemungutan suara sudah berumur tujuh belas tahun atau lebih atau sudah/pernah menikah, mempunyai hak memilih. Seorang warga negara Indonesia yang telah mempunyai hak memilih, baru bisa menggunakan haknya, apabila telah terdaftar sebagai pemilih

Melalui Pilkada, sebagaimana dikatakan oleh Yusdianto (2010: 44), rakyat dapat memilih siapa yang menjadi pemimpin dan wakilnya dalam proses penyaluran aspirasi, yang selanjutnya menentukan arah masa depan sebuah negara. 
Pemberlakuan UU Nomor 10 tahun 2016 ini merupakan komitmen pemerintah dalam melaksanakan demokrasi di Indonesia. Rakyat tidak hanya bebas menentukan Presiden dan wakil presidennya, tetapi juga bebas memilih gubernur, bupati dan walikota serta wakilnya secara langsung, sehingga diharapkan dapat terpilih putra-putra terbaik daerah yang mampu membangun dan mengembangkan daerahnya sesuai dengan kebutuhan pembangunan.

Persoalan kemudian muncul ketika dalam proses pemilihan kandidat atau calon yang akan dipilih tidak melalui proses demokrasi yang ideal. Dengan kata lain, para calon ini ditentukan oleh pengurus pusat partai politik. Sementara pengurus partai politik di daerah tidak memiliki kewenangan yang otonom, tidak ada desentralisasi kewenangan dari Dewan Pimpinan Pusat (DPP) kepada Dewan Pimpinan Daerah (DPW) atau Dewan Pimpinan Cabang (DPC) untuk menentukan calon.

\section{Partai Politik}

Dari sisi teori kekuasaan jelas, parpol memang anak tangga untuk memperoleh dan melanjutkan tapuk kekuasaan. Carl J. Friedrich (dikutif dalam Miriam Budiardjo,2008:404) mendefinisikan partai politik sebagai kelompok manusia yang terorganisir untuk merebut atau mempertahankan kekuasaan, dengan maksud mensejahterakan anggotanya, baik untuk kebijaksaanaan keadilan, maupun untuk hal-hal yang bersifat materil

Dalam pandangan Richard Katz dan Peter Mair (www.google.com/wajahparpol-menurut-Katz-Mier/kompas.com, 29 Mei 2013) dalam The Evolution of Party Organizations in Europe: Three Faces of Party Organization (1994). Menurut mereka, partai politik sejatinya memiliki tiga wajah: Pertama, party in publik office yaitu partai politik dengan keterwakilan kader di parlemen (DPR) dan jajaran pemerintahan (menteri). Pada wajah ini, kader-kader partai melakukan maksimalisi untuk kesempatan politik (political opportunity) untuk melakukan agenda politik partai. Selain itu mereka-mereka ini juga 
mengoptimalkan usaha-usaha untuk pendanaan partai politik. Gesekan antar partai di Parlemen ataupun pemerintahan menjadi sangat kentara. Kedua, party in the ground yaitu aktivitas partai diakar rumput yang menjadi jantung dari pemeliharaan lumbung suara partai politik. Pada tahap ini agenda-agenda parpol terus dikonsolidasikan dan proses mobilisasi sumber daya (resource mobilizations) dilakukan untuk menjaring calon-calon anggota legislatif yang berintegritas dan memiliki kapabilitas. Kinerja masing-masing level parpol ini, baik pusat maupun akar rumput (daerah) menjadi unjung tombak yang dapat memicu minat dan ketertarikan rakyat. Ketiga, party in the central office yaitu aktivitas partai yang berada dipusat yang melakukan ragam konsolidasi, taktik, dan strategi dalam memenangkan pemilu. Pada tahap ini partai politik membentuk strategi, dan upaya-upaya untuk menarik minat masyarakat agar partai menang dalam pemilu.

Russell J. Dalton, dan Martin P. Wattenberg menggambarkan fungsi partai politik secara lebih lengkap dari setiap bagian (dikutip dalam Sigit Pamungkas, 2010:15), yaitu: Pertama adalah fungsi partai di elektorat (parties in the electorate). Pada bagian ini fungsi partai menunjuk pada penampilan partai politik dalam menghubungkan individu dalam proses demokrasi. Kedua, adalah fungsi partai sebagai organisasi (parties as organization). Pada fungsi ini menunjuk pada fungsi-fungsi yang melibatkan partai sebagai organisasi politik, atau proses-proses didalam organisasi partai itu sendiri. Ketiga, adalah fungsi partai dipemerintahan (parties in government). Pada arena ini, partai bermain dalam pengelolaan dan penstrukturan persoalan-persoalan pemerintahan.

Aturan tentang parpol di negeri ini cukup lengkap. Artinya parpol ideal sesungguhnya sudah digariskan seperti menurut regulasi yang ada. Peraturan perundang-undangan yang mengatur tentang Partai Politik di Indonesia sejak masa merdeka adalah: 1) Maklumat X Wakil Presiden Muhammad Hatta (1945); 2) Undang-Undang Nomor 7 Pnps Tahun 1959 tentang Syarat-Syarat 
dan Penyederhanaan Kepartaian; 3) Undang-Undang Nomor 13 Tahun 1960 tentang Pengakuan, Pengawasan, dan Pembubaran Partai-Partai; 4) UndangUndang Nomor 3 tahun 1975 tentang Partai Politik dan Golongan Karya; 5) Undang-Undang Nomor 3 tahun 1985 tentang Perubahan Atas Undang-Undang Nomor 7 Tahun 1975 tentang Partai Politik dan Golongan Karya; 6) UndangUndang Nomor 2 Tahun 1999 tentang Partai Politik; 7) Undang-Undang Nomor 31 Tahun 2002 tentang Partai Politik; 8) Undang-Undang Nomor 2 Tahun 2008 tentang Partai Politik.

Indonesia sudah mengenal partai politik jauh sebelum merdeka. Pada zaman kolonial, tokoh-tokoh pergerakan menggunakan partai politik sebagai alat perjuangan. Itu sebabnya ketika Wakil Presiden Mohamad Hatta mengeluarkan Maklumat X pada Oktober 1945, partai-partai politik yang sempat tiarap pada zaman Jepang, bangkit kembali.

Partai politik yang dibentuk oleh para bangsawan (elit) beroperasi secara top-down dengan fungsi utamanya memobilisasi massa bagi legitimasi kekuasaan. Sebaliknya, partai bentukan masyarakat beroperasi secara bottomup dengan fungsi utamanya adalah menyalurkan dan menyampaikan aspirasi masyarakat ke dalam sistem politik.

Partai politik bentukan elit sering disebut partai elit (elite party) atau partai kaukus (caucus party), sementara partai bentukan masyarakat disebut partai massa (mass party). Dikotomi partai elit dan partai massa merupakan cerminan ideologi yang dianut oleh masing-masing partai politik.

Menurut Kirchheimer (dikutip dalam Ichlasul Amal, 2000: 71-90) partai politik pun mulai mengembangkan karakter baru yakni partai lintas kelompok atau catch-all party. Format catch-all party kemudian melahirkan paradigm pragmatisme dan rasionalitas partai politik dalam menyangga sistem politik demokratis. Inilah barangkali yang menyebabkan parpol di Indonesia, khususnya pascareformasi, luntur ideologinya. 
Dalam perkembanganya kemudian fungsi utama partai politik justru hanya menjadi mesin pendulang suara dalam usaha memenangkan pemilu. Fungsi-fungsi yang seharusnya melekat pada partai politik seperti fungsi sosialisasi politik, komunikasi politik, pendidikan politik, rekrutmen politik, pengendali konflik dan kontrol politik justru tidak dilaksanakan sebagaimana mestinya. Padahal, parpol ideal berbanding lurus dengan kedaulatan rakyat, semakin berdaulat rakyat semakin ideal parpolnya. Maka, jika parpolnya belum juga ideal itu pertanda rakyatnya belum berdaulat.

\section{Anomali Kewenangan DPP Partai Politik}

Demokrasi sebagai perwujudan kedaulatan rakyat, direpresentasikan melalui desentralisasi baik secara administratif maupun politik. Secara politik desentralisasi diwujudkan dalam bentuk pemilihan kepala daerah langsung, baik ditingkat provinsi maupun kota/kabupaten. Sebagaimana Tip O"Neill (1995) „all politics is local", yang berarti bahwa demokrasi akan berkembang subur dan terbangun kuat di aras nasional apabila di tingkatan yang lebih rendah (local) nilai-nilai demokrasi berakar kuat.

Dengan demikian, desentralisasi politik sebagai bagian integral proses demokratisasi seharusnya dapat diwujudkan dalam sistem politik di dalam partai politik sesuai dengan tingkatan. Namun pada kenyataannya proses pelimpahan wewenang dari pengurus partai politik ditingkat pusat ke pengurus ditingkat daerah tidak berjalan dalam struktur partai politik. Terutama dalam kebijakan penentuan calon atau kandidat yang akan dipilih rakyat cenderung diputuskan ditingkat pimpinan pusat. Pengurus di daerah hanya sebatas mengusulkan kandidat, namun keputusan maju atau tidaknya kandidat yang diusulkan pengurus partai politik di daerah ditentukan oleh pusat.

Kondisi ini tentu tidak sesuai dengan azas demokrasi yang menempatkan kedaulatan ada ditangan rakyat. Kader-kader partai didaerah, sebagai konstituen pemilih yang memperjuangkan hak politiknya melalui partai 
politik tidak memiliki ruang yang cukup dalam menyalurkan hak partisipatifnya. Disisi lain tampaknya partai politik enggan melepaskan wewenangnya terhadap daerah, terutama dalam pengelolaan sumber kekayaan didaerah.

Dalam pengertian lain, partai poltik ditingkat pusat menciptakan ketergantungan terhadap calon/kandidat pemimpin politik di daerah. Kondisi ini menjadikan pimpinan politik ditingkat daerah sangat mudah diintervensi oleh kepentingan-kepentingan partai politik. Sebut salah satunya adalah pemimpin politik ditingkat daerah yang berhasil menduduki posisi kepala daerah diharuskan memenangkan partai pengusungnya dalam kontestasi pileg maupun pilpres. Padahal, ketika seorang kandidat berhasil terpilih menjadi kepala daerah maka keberadaannya tidak lagi menjadi milik partai politik, tapi menjadi pemimpin rakyat didaerahnya.

Hegemoni dan sentralisasi DPP partai politik secara regulasi merupakan sebuah keniscayaan. Hal ini dapat dilihat di dalam Peraturan KPU Nomor 9 Tahun 2015 tentang Pencalonan, pemilihan Gubernur dan Wakil Gubernur, Bupati dan Wakil Bupati, dan/atau Walikota dan Wakil Walikota pasal 38 ayat (1) dan ayat (1a) ; Partai Politik atau Gabungan Partai Politik wajib memenuhi persyaratan: (b). menyertakan Keputusan Pimpinan Partai Politik tingkat pusat tentang persetujuan Pasangan Calon dan dokumen syarat calon.

Kenyataan ini pada akhirnya mengakibatkan banyak kandidat atau calon yang langsung berhubungan dengan pengurus pusat untuk mendapatkan rekomendasi. Proses-proses komunikasi dan koordinasi ditingkat wilayah sudah tidak dianggap perlu. Di sisi lain berkembang anggapan komunikasi dan koordinasi dengan pengurus daerah hanya akan menghabiskan uang tanpa memberi kepastian yang berarti. Padahal dalam pelaksanakan pemenangan kontestasi pengurus dan kader di daerahlah yang menjadi ujung tombak.

Sentralisasi kekuasaan dalam struktur partai politik pada giliranya mematikan semangat kompetisi yang sehat ditingkat lokal. Seseorang tidak 
harus merintis menjadi anggota/pengurus partai dari tingkat bawah untuk menjadi kandidat yang diusung partai politik. Bahkan orang yang diluar partai pun (bukan kader) bisa diusung menjadi calon/kandidat partai politik. Padahal proses pendidikan politik yang ditempa dalam karier politik sangatlah penting dalam menciptakan pemimpin politik yang matang dalam mengelola berbagai konflik kepentingan didalam sebuah organisasi, termasuk dipemerintahan yang sangat heterogen.

Selain itu pemimpin-pemimpin politik instan yang dipilih karena popularitas berdampak buruk terhadap spirit kompetisi antar kader, gejala adanya transaksional dalam jual beli dukungan sangat terasa. Jika dalam proses pengusungan telah terjadi transaksional tentu tidak banyak yang bisa diharapkan dari kandidat yang diusung. Sebab ketika kandidat tersebut terpilih menjadi kepala daerah, maka dirinya akan tersandera oleh kepentingan partai pengusung, dan bukan pada masyarakat pemilih.

\section{Simpulan dan Saran}

Kecenderungan partai politik sentralistis dan menafikan suara arus bawah tidak saja mematikan proses-proses demokrasi dalam tubuh partai politik. Tetapi berdampak pada mengakarnya politik transaksional dari hulu hingga hilir. Seorang kandidat untuk dapat diusulkan dan mendapat dukungan partai politik untuk maju tak jarang harus mengeluarkan mahar politik, walaupun dalam "bahasa halus" sering disebut operasional pemenangan atau ongkos politik.

Mencermati kondisi tersebut tentu perlu adanya perubahan signifikan dalam struktur partai politik. Partai poltik harus dibangun atas landasan kebersamaan dalam perjuangan politik dan bukan hanya sekedar ambisi pribadi maupun salah satu golongan dalam mencapai kekuasaan. Partai politik harus menjadi wadah pendidikan politik untuk melahirkan pemimpin-pemimpin politik lokal yang siap bersaing ditingkat nasional bahkan global. 
Dengan kata lain, partai politik harus mulai menerapkan desentralisasi kekuasaan kepada wilayah dan daerah, sehingga daerah memiliki peluang untuk mengembangkan dirinyanya. Selain tentunya ada kepastian karier bagi para kader partai politik.

Untuk mewujudkan hal tersebut tentu yang pertama adalah merubah peraturan KPU no 9 tahun 2015. Syarat adanya surat keputusan dari pengurus pusat perlu direvisi dan dibatasi hanya pada tingkat nasional. Dengan kata lain, keputusan-keputusan pengusungan calon/kandidat yang akan maju dalam kontestasi disesuaikan dengan tingkat wilayah. Untuk tingkat tingkat calon presiden, surat keputusan dikeluarkan oleh pimpinan pusat. Sementara untuk provinsi cukup Surat Keputusan dukungan dari partai poltik tingkat provinsi, demikian halnya ditingkat kota dan kabupaten, DPP mungkin cukup hanya mendapat laporan saja dan cukup mengetahui.

Dengan adanya pelimpahan wewenang dari pusat kepada pengurus partai didaerah berdampak positif pada pengembangan partai politik dan proses pemberdayaan kader partai yang sehat dan fair. Diharapkan dengan pola seperti ini dapat terwujud pemimpin-pemimpin politik ditingkat lokal dan nasional, ini yang pertama.

Kedua, sistem politik demokratis perlu dikuatkan dan dipertegas dalam kepemimpinan politik ditingkat lokal, bahwa keberadaan kepala daerah merupakan representasi seluruh masyarakat didaerah tersebut. Dengan kata lain, ketika seorang kandidat terpilih menjadi kepada daerah maka ia harus melepaskan diri dari ikatan-ikatan partai politik pengusung. Keberadaannya harus dikembalikan menjadi milik publik dan bukan milik kelompok tertentu. Termasuk kewajibannya dalam mendukung atau memenangkan salah satu calon/parpol dalam kegiatan pemilu diseluruh tingkatan. Keberadaannya sebagai kepala daerah harus bersikap netral untuk menjamin mesin birokrasi berjalan sesuai fungsinya, yaitu pelayanan publik dan pembangunan. 
Ketiga, membangun sistem politik yang lebih demokratis dalam struktur partai politik. Tidak dapat dipungkiri, kehadiran partai-partai politik di Indonesia sangat bergantung pada figur tertentu. Baik figur pengusaha dengan kekuatan kapitalnya maupun figur dengan kekuatan latar belakang keluarga maupun ideologi.

Kecenderungan partai politik terhadap kekuatan seorang figure dapat menjadi boomerang terhadap eksistensi partai. Sebut misalkan partai politik yang menyandarkan eksistensinya kepada pengusaha, maka apakah partai akan tetap eksis jika pengusaha tersebut tidak lagi menyuplai kebutuhan operasional partai? Pada kenyataannya ketergantungan terhadap figur ini menciptakan struktur partai ditingkat bawah tidak memiliki posisi tawar memadai. Keberadaannya tidak lagi memperjuangkan partai tetapi lebih pada memperjuangkan kepentingan si „empunya" partai. Untuk itu ruang demokrasi perlu dibangun dalam struktur partai untuk menciptakan banyak figur kader yang mampu menjadi pemimpin, sehingga tidak terpusat dan tergantung pada satu figur.

\section{DAFTAR PUSTAKA}

\section{Buku:}

1. Amal, Ichlasul. 2000. Hubungan Pusat-Daerah dalam Pembangunan. Jakarta: PT. Raja Grafindo

2. Apter, David, E., Setiawan Abadi (pnjh.), 1995. Pengantar Analisa Politik, Jakarta: LP3ES.

3. Azis, Noor M. 2011. Pengkajian Hukum Tentang Pemilihan Kepala Daerah. Jakarta: Badan Pembinaan Hukum Nasional Kementerian Hukum dan Hak Asasi Manusia Republik Indonesia.

4. Budiardjo, Miriam. 1998. Menggapai Kedaulatan Untuk Rakyat, Bandung: Mizan 
5. Dahl, Robert A. 2001. Perihal Demokrasi, terj. A. Rahman Zainuddin, Jakarta: Yayasan. Obor Indonesia.

6. Haris, Syamsuddin. 2007. Desentralisasi dan Otonomi Daerah. Jakarta. LIPPI press.

7. Held, David. 1996. Model of Democracy, Stanford University Press, Cambridge

8. Huntington, Samuel P. 1995. Gelombang Demokratisasi Ketiga. Jakarta: Pustaka Utama Grafiti.

9. Kaho, Josef Riwu, 1997. Prospek Otonomi Daerah di Negara Republik Indonesia. Jakarta : PT Raja Grafindo Persada

10. O'Nell. 1995

11. Pamungkas, Sigit, 2010. Pemilu: Perilaku Pemilih an Kepartaian. Yogyakarta: Institute for Demokrasi.

12. Schumpeter, Yoseph A. 1992. Capitalism, Socialism and Democracy, London: George Allen, Lt.

13. Smith, D Ronald, 2003. Strategic Planning for Publik Relations, second edition, London: Laurence Erlbaum Associates Publisher.

14. Sorensen, George. 2003. Demokrasi dan Demokratisasi: Proses dan Prospek dalam Sebuah Dunia yang sedang Berubah. (Edisi Terjemahan). Yogyakarta : Pustaka Pelajar.

15. Suharizal. 2011. Pemilukada: Regulasi, Dinamika, dan Konsep Mendatang. Jakarta: Rajagrafindo Persada.

16. Surbakti, Ramlan. 1992. Memahami Ilmu Politik. Jakarta: PT Gramedia Widiasarana Indonesia.

17. Treanor, Paul. 2001. Kebohongan Demokrasi, Yogyakarta: Institut Tafsir Wacana (ISTAWA). 


\section{Jurnal}

1. Warganegara, Arizka. 2011. Demokratisasi Dan Partai Politik Di Indonesia (Tinjauan Teoritik Huntington Dan Lijphart)Jurnal Ilmiah Administrasi Publik dan Pembangunan, Vol.2, No.2, Juli - Desember 2011

2. Yusdianto, Identifikasi Potensi Pelanggaran Pemilihan Kepala Daerah (Pemilukada) dan Mekanisme PenyelesaiiannyaI. Jurnal Konstitusi Vol II nomor 2, November 2010: 40-60.

\section{Regulasi:}

1. UU No.23/ 2014 tentang Pemerintahan Daerah.

2. Peraturan KPU Nomor 9 Tahun 2015 tentang Pencalonan, pemilihan Gubernur dan Wakil Gubernur, Bupati dan Wakil Bupati, dan/atau Walikota dan Wakil Walikota

\section{Internet:}

1. http://m.republika.co.id/berita/nasinal/pilkada/17/10/28, diunduh 04/01/ 18.

2. http://metrotvnews.com/read/2017/11/07/78462/kader-golkar-bakallaporkan-pengusungan-emil-ke-mahkamah-partai, diunduh 04/01/18.

3. http://regional.kompas.com/read/2018/01/07, diunduh tanggal 08/01/17

4. http://m.republika.co.id/berita/nasional/pilkada/1708/10, diunduh tanggal 08/01/18

5. https://m.detik.com/news/berita-jawa-barat/d-3713199/demokratbandung-rekomendasikan-yossi-ke-dpp-jadi-calon-wali-kota, diunduh 08/01/18

6. http://m.liputan6.com/news/read/3157712/demokrat-usung-nurul-arifinchairul-yaqin-untuk-pilwalkot-bandung, diundul 08/01/18

7. www.google.com/wajah-parpol-menurut-Katz-Mier/kompas.com, 29 Mei 2013. 